\title{
Combination of Tris(pentafluorophenyl)borane and Trialkylsilyl Triflate as an Efficient Catalyst System for the Group Transfer Polymerization of Acrylates
}

\author{
Koichi Ute, ${ }^{\dagger}$ Hidetaka OHNUma, and Tatsuki Kitayama \\ Department of Chemistry, Graduate School of Engineering Science, \\ Osaka University, Toyonaka, Osaka 560-8531, Japan
}

(Received August 14, 2000; Accepted September 13, 2000)

\begin{abstract}
KEY WORDS Lewis Acid / Ketene Silyl Acetal / Poly(ethyl acrylate) / Poly(methyl metacrylate) / Living Polymerization / Tacticity / Block Copolymerization /
\end{abstract}

Group transfer polymerization (GTP) is a convenient method to prepare polymethacrylates and polyacrylates with narrow molecular weight distributions (MWDs) at room temperature. ${ }^{1,2}$ For the GTP of methacrylates nucleophilic catalysts ${ }^{3}$ and polar solvents are most suitable for achieving a living polymerization. On the other hand, Lewis acid catalysts and nonpolar solvents are preferred for the GTP of acrylates. The use of nucleophilic catalysts and polar solvents in acrylate GTP leads to broad MWDs. ${ }^{2,4}$ Examples of Lewis acid catalysts include zinc halides and dialkylaluminum halides. The drawback of these catalysts is that large amounts of catalysts (e.g., zinc halides), usually 10 mol\% based on monomer, or low temperatures (e.g., dialkylaluminum halides) are required. Although $\mathrm{HgI}_{2}$ catalysis can overcome this limitation, ${ }^{5,6}$ toxic reaction mixtures are inconvenient to handle. Trifluoromethanesulfonate (triflate) salts of lanthanides $\left[\mathrm{La}(\mathrm{OTf})_{3}, \mathrm{Sm}(\mathrm{OTf})_{3}, \mathrm{Y}(\mathrm{OTf})_{3}\right]$ are also claimed to be effective as Lewis acid catalysts for acrylate GTP. ${ }^{7}$ However, the catalytic activity of lanthanide triflates seems to be lower than that of $\mathrm{HgI}_{2}$.

Dicker has disclosed that a trialkylsilyl compound such as $\left(\mathrm{CH}_{3}\right)_{3} \mathrm{SiI}$ or $\left(\mathrm{CH}_{3}\right)_{3}$ SiOTf catalyzes GTP of acrylates preferably in the presence of a Lewis acid such as $\mathrm{HgI}_{2}$ or zinc halides. ${ }^{8}$ Zhuang and Müller have reported that the $\mathrm{HgI}_{2}$-catalyzed GTP of $n$-butyl acrylate is drastically accelerated in the presence of $\left(\mathrm{CH}_{3}\right)_{3} \mathrm{SiI}^{9-11}$ The $\mathrm{HgI}_{2}-\left(\mathrm{CH}_{3}\right)_{3} \mathrm{SiI}$ system is so efficient that methyl crotonate can be homopolymerized in a quantitative yield. ${ }^{12,13}$ Interestingly, this GTP shows high stereospecificity leading to the formation of disyndiotactic poly(methyl crotonate). ${ }^{13}$ These findings prompted us to explore the combination of Lewis acid (e.g., alkylaluminum bis(2,6-di-tert-butylphenoxide)) and silylating agent (e. g., trialkylsilyl triflate, $\mathrm{R}_{3} \mathrm{SiOTf}$ ) as a catalyst system for the GTP of acrylic monomers. ${ }^{14,15}$

Here we report very efficient GTP of acrylates promoted by $\mathrm{B}\left(\mathrm{C}_{6} \mathrm{~F}_{5}\right)_{3}$ and $\mathrm{R}_{3}$ SiOTf. The amounts of $\mathrm{B}\left(\mathrm{C}_{6} \mathrm{~F}_{5}\right)_{3}$ and $\mathrm{R}_{3} \mathrm{SiOTf}$ required for the catalysis are 0.01 $-0.1 \mathrm{~mol} \%$ and $0-0.001 \mathrm{~mol} \%$, respectively, relative to monomer. A variety of organic reactions employing $\mathrm{B}\left(\mathrm{C}_{6}\right.$ $\left.\mathrm{F}_{5}\right)_{3}$ as the Lewis acid catalyst have been studied by Ishihara and co-workers. ${ }^{16,17}$ Sugimoto and co-workers dem-

\footnotetext{
${ }^{\dagger}$ To whom correspondence should be addressed.
}

onstrated that $\mathrm{B}\left(\mathrm{C}_{6} \mathrm{~F}_{5}\right)_{3}$ accelerates the living polymerization of methyl methacrylate with methylaluminum tetraphenylporphyrin. ${ }^{18}\left(\mathrm{CH}_{3}\right)_{3}$ SiOTf is also known to catalyze aldol-type condensation of enol silyl ethers and acetals. ${ }^{19,20}$ However, no study has been reported on the synergetic effects of $\mathrm{B}\left(\mathrm{C}_{6} \mathrm{~F}_{5}\right)_{3}$ and $\mathrm{R}_{3}$ SiOTf.

The GTP of ethyl acrylate was initiated by adding a $\mathrm{CH}_{2} \mathrm{Cl}_{2}$ solution of 1-methoxy-1-(triethylsiloxy)-2methyl-1-propene (1) to the mixture of ethyl acrylate, catalysts, and $\mathrm{CH}_{2} \mathrm{Cl}_{2}$. As shown in Table I, both $\mathrm{B}\left(\mathrm{C}_{6} \mathrm{~F}_{5}\right)_{3}$ and $\left(\mathrm{C}_{2} \mathrm{H}_{5}\right)_{3}$ SiOTf were found effective as catalysts for the GTP. Particularly, $\mathrm{B}\left(\mathrm{C}_{6} \mathrm{~F}_{5}\right)_{3}$ is useful because only a small amount is needed to attain a practical rate of polymerization. The $B\left(\mathrm{C}_{6} \mathrm{~F}_{5}\right)_{3}$-catalyzed GTP, in which $1 \mathrm{~mol} \%$ initiator and $0.1 \mathrm{~mol} \% \quad \mathrm{~B}\left(\mathrm{C}_{6} \mathrm{~F}_{5}\right)_{3}$ were used, proceeded rapidly at $20^{\circ} \mathrm{C}$ to give poly(ethyl acrylate) with a narrow MWD (yield $91 \%$, polymerization for $1 \mathrm{~h})$. When $0.001 \mathrm{~mol} \%\left(\mathrm{C}_{2} \mathrm{H}_{5}\right)_{3}$ SiOTf was added to the $\mathrm{B}\left(\mathrm{C}_{6} \mathrm{~F}_{5}\right)_{3}$-catalyzed GTP, polymerization proceeded more rapidly and completed within $1 \mathrm{~h} . M_{\mathrm{n}}$ of the resulting polymer as determined by ${ }^{1} \mathrm{H}$ NMR end-group analysis agreed well with the expected value, indicating nearly $100 \%$ initiator efficiency. It was thus possible to control $M_{\mathrm{n}}$ by the feed ratio of monomer to initiator in the $\mathrm{B}\left(\mathrm{C}_{6} \mathrm{~F}_{5}\right)_{3}$-catalyzed GTP with $\left(\mathrm{C}_{2} \mathrm{H}_{5}\right)_{3}$ SiOTf.

The effects of $\left(\mathrm{C}_{2} \mathrm{H}_{5}\right)_{3}$ SiOTf were more pronounced in the $\mathrm{B}\left(\mathrm{C}_{6} \mathrm{~F}_{5}\right)_{3}$-catalyzed GTP at $0^{\circ} \mathrm{C}$. The $\mathrm{B}\left(\mathrm{C}_{6} \mathrm{~F}_{5}\right)_{3}$ catalyzed GTP in the presence of $\left(\mathrm{C}_{2} \mathrm{H}_{5}\right)_{3} \mathrm{SiOTf}$ afforded poly(ethyl acrylate) with a narrow $\operatorname{MWD}\left(M_{\mathrm{w}} / M_{\mathrm{n}}=1.18\right)$, whereas that in the absence of $\left(\mathrm{C}_{2} \mathrm{H}_{5}\right)_{3}$ SiOTf gave poly(ethyl acrylate) with a somewhat broad MWD $\left(M_{\mathrm{w}} / M_{\mathrm{n}}=\right.$ 1.52). The latter polymer had a large $M_{\mathrm{n}}$ as compared with the former whose $M_{\mathrm{n}}$ was close to the predicted value (Table I).

Though its mode of action is not known with certainty, $\left(\mathrm{C}_{2} \mathrm{H}_{5}\right)_{3} \mathrm{Si}^{+}$species produced by the reaction of $\left(\mathrm{C}_{2} \mathrm{H}_{5}\right)_{3}$ SiOTf with $\mathrm{B}\left(\mathrm{C}_{6} \mathrm{~F}_{5}\right)_{3}$ should be responsible for the cooperative catalysis in this GTP. Since the GTP proceeds even in the absence of $\left(\mathrm{C}_{2} \mathrm{H}_{5}\right)_{3} \mathrm{SiOTf}$, a catalytic amount of $\left(\mathrm{C}_{2} \mathrm{H}_{5}\right)_{3} \mathrm{Si}^{+}$species is supposed to be formed directly from ketene triethylsilyl acetals (initiator and the growing site of a polymer chain) through the action of $\mathrm{B}\left(\mathrm{C}_{6} \mathrm{~F}_{5}\right)_{3}$.

The living nature of this GTP was affected by the structure of trialkylsilyl groups in the initiator and cata- 
Table I. Group transfer polymerization of ethyl acrylate catalyzed by $\mathrm{B}\left(\mathrm{C}_{6} \mathrm{~F}_{5}\right)_{3}$ and $\left(\mathrm{C}_{2} \mathrm{H}_{5}\right)_{3} \mathrm{SiOTf}_{\text {in }} \mathrm{CH}_{2} \mathrm{Cl}_{2}{ }^{a}$

\begin{tabular}{|c|c|c|c|c|c|c|c|c|c|}
\hline Initiator ${ }^{b}$ & $\mathrm{~B}\left(\mathrm{C}_{6} \mathrm{~F}_{5}\right)_{3}$ & $\left(\mathrm{C}_{2} \mathrm{H}_{5}\right)_{3} \mathrm{SiOTf}$ & Temp & Time & Yield & & $M_{\mathrm{n}}$ & & $M_{\mathrm{w}}{ }^{\mathrm{c}}$ \\
\hline$\mu \mathrm{mol}$ & $\mu \mathrm{mol}$ & $\mu \mathrm{mol}$ & ${ }^{\circ} \mathrm{C}$ & $\mathrm{h}$ & $\%$ & calcd $^{c}$ & $\mathrm{NMR}^{\mathrm{d}}$ & $\mathrm{SEC}^{\mathrm{e}}$ & $M_{\mathrm{n}}$ \\
\hline 200 & 0 & 100 & 0 & 24 & 74 & 3800 & & 3200 & 2.35 \\
\hline 200 & 10 & 0 & 0 & 1 & 100 & 5100 & & 7500 & 1.52 \\
\hline 200 & 10 & 0.10 & 0 & 1 & 100 & 5100 & 5300 & 6800 & 1.18 \\
\hline 100 & 10 & 0 & 20 & 1 & 91 & 9200 & & 12600 & 1.13 \\
\hline 100 & 10 & 0.10 & 20 & 1 & 100 & 10100 & $10500^{f}$ & 15100 & 1.14 \\
\hline 50 & 10 & 0.10 & 20 & 4 & 100 & 20100 & 21700 & 36000 & 1.16 \\
\hline
\end{tabular}

${ }^{a}$ Ethyl acrylate $10 \mathrm{mmol}, \mathrm{CH}_{2} \mathrm{Cl}_{2} 4.0 \mathrm{~mL}$. ${ }^{b}$ Initiator $\mathrm{1},\left(\mathrm{CH}_{3}\right)_{2} \mathrm{C}=\mathrm{C}\left(\mathrm{OCH}_{3}\right) \mathrm{OSi}\left(\mathrm{C}_{2} \mathrm{H}_{5}\right)_{3} .{ }^{c}$ Calculated from the yield and the feed ratio of monomer to initiator at $100 \%$ initiator efficiency. ${ }^{d}$ Determined by ${ }^{1} \mathrm{H}$ NMR end-group analysis (based on the relative intensity of the $\mathrm{OCH}_{2}$ resonances at $4.01-4.21 \mathrm{ppm}$ to the terminal $\mathrm{OCH}_{3}$ resonances at $3.60-3.68 \mathrm{ppm}$, measured in $\mathrm{CDCl}_{3}$ at $55^{\circ} \mathrm{C}$ and $500 \mathrm{MHz}$ ). ${ }^{\mathrm{e}} \mathrm{Deter}-$ mined by size exclusion chromatography calibrated against standard PMMAs (two PLgel Mixed-C columns $7.5 \times 300 \mathrm{~mm}$; eluent, tetrahydrofuran). ${ }^{\mathrm{f}}$ Diad tacticity determined by ${ }^{1} \mathrm{H}$ NMR, $m / r=36 / 64$.

Table II. Group transfer polymerization catalyzed by the Lewis acid - silylating agent (SA) system ${ }^{\text {a }}$

\begin{tabular}{|c|c|c|c|c|c|c|c|c|}
\hline \multirow{2}{*}{ Monomer } & Initiator $^{b}$ & $\mathrm{~B}\left(\mathrm{C}_{6} \mathbf{F}_{5}\right)_{3}$ & SA & \multirow{2}{*}{ Solvent } & Temp & Time & \multirow{2}{*}{$M_{\mathrm{n}}{ }^{\mathrm{c}}$} & $M_{\mathrm{w}}{ }^{\mathrm{c}}$ \\
\hline & $\mu \mathrm{mol}$ & $\mu \mathrm{mol}$ & $\mu \mathrm{mol}$ & & ${ }^{\circ} \mathrm{C}$ & $\mathrm{h}$ & & $M_{\mathrm{n}}$ \\
\hline Ethyl acrylate & $\begin{array}{r}2 \\
100\end{array}$ & 10.0 & $\begin{array}{c}\left(\mathrm{CH}_{3}\right)_{3} \mathrm{SiOTf} \\
0.10\end{array}$ & $\mathrm{CH}_{2} \mathrm{Cl}_{2}$ & 20 & 1 & 14700 & 1.26 \\
\hline Ethyl acrylate & $\begin{array}{r}\mathbf{2} \\
100\end{array}$ & 1.0 & $\begin{array}{c}\left(\mathrm{CH}_{3}\right)_{3} \mathrm{SiO} \mathrm{Tf} \\
0.010\end{array}$ & $\mathrm{CH}_{2} \mathrm{Cl}_{2}$ & 0 & 1 & 15300 & 1.15 \\
\hline Ethyl acrylate & $\begin{array}{r}2 \\
100\end{array}$ & 5.0 & $\begin{array}{c}\left(\mathrm{CH}_{3}\right)_{3} \mathrm{SiOTf} \\
0.10\end{array}$ & Toluene & 0 & 4 & 17300 & 1.12 \\
\hline Methyl methacrylate & $\begin{array}{r}1 \\
100\end{array}$ & 200 & $\begin{array}{c}\left(\mathrm{C}_{2} \mathrm{H}_{5}\right)_{3} \mathrm{SiI} \\
50\end{array}$ & $\mathrm{CH}_{2} \mathrm{Cl}_{2}$ & 0 & 2 & 12100 & 1.06 \\
\hline Methyl methacrylate & $\begin{array}{r}1 \\
200\end{array}$ & 200 & $\begin{array}{c}\left(\mathrm{C}_{2} \mathrm{H}_{5}\right)_{3} \mathrm{SiI} \\
100\end{array}$ & $\mathrm{CH}_{2} \mathrm{Cl}_{2}$ & -40 & 24 & $7400^{d}$ & 1.12 \\
\hline
\end{tabular}

${ }^{\text {a }}$ Monomer $10 \mathrm{mmol}$, solvent $4.0 \mathrm{~mL}$. A quantitative yield of polymer was obtained. ${ }^{\mathrm{b}}$ Initiator: $\mathbf{1},\left(\mathrm{CH}_{3}\right)_{2} \mathrm{C}=\mathrm{C}\left(\mathrm{OCH}_{3}\right) \mathrm{OSi}_{1}\left(\mathrm{C}_{2} \mathrm{H}_{5}\right)_{3} ; \mathbf{2}$, $\left(\mathrm{CH}_{3}\right)_{2} \mathrm{C}=\mathrm{C}\left(\mathrm{OCH}_{3}\right) \mathrm{OSi}\left(\mathrm{CH}_{3}\right)_{3}$. ${ }^{\mathrm{c}}$ Determined by size exclusion chromatography calibrated against standard PMMAs. ${ }^{\mathrm{d}}$ Triad tacticity determined by ${ }^{1} \mathrm{H}$ NMR: $\mathrm{mm} / \mathrm{mr} / \mathrm{rr}=0 / 12 / 88$.

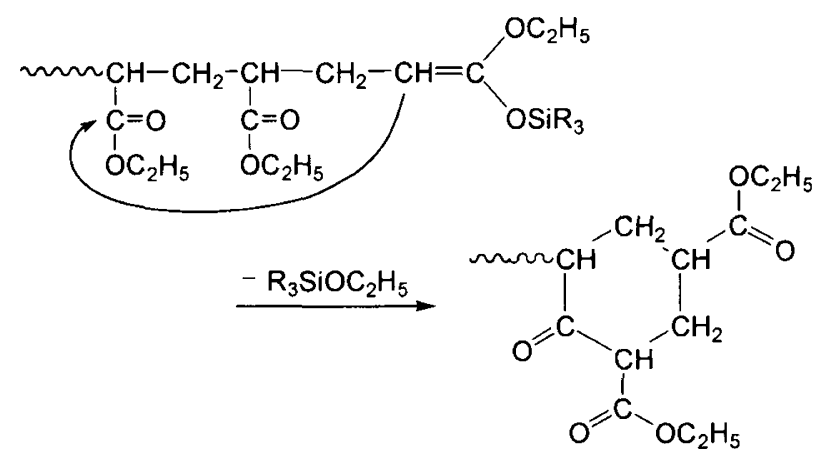

Scheme 1. Self-termination of living poly(ethyl acrylate) through cyclization.

lyst. At a polymerization temperature of $20^{\circ} \mathrm{C}$, the use of 1-methoxy-1-(trimethylsiloxy)-2-methyl-1-propene (2) as the initiator and $\mathrm{B}\left(\mathrm{C}_{6} \mathrm{~F}_{5}\right)_{3}-\left(\mathrm{CH}_{3}\right)_{3}$ SiOTf as the catalyst resulted in the formation of polymers with broader MWDs than those prepared by the corresponding $\left(\mathrm{C}_{2} \mathrm{H}_{5}\right)_{3} \mathrm{Si}$ - system (Table II). The ketene trimethylsilyl acetal at the chain-end of growing polymer would be more liable to deactivation, probably through intramolecular cyclization (Scheme 1). ${ }^{21} \mathrm{~A}$ similar tendency has been observed in the $\mathrm{HgI}_{2}$-catalyzed GTP of methyl crotonate. $^{13}$

The $\left(\mathrm{CH}_{3}\right)_{3} \mathrm{Si}$ - system gave poly(ethyl acrylate) with a narrow MWD when the GTP was carried out at $0^{\circ} \mathrm{C}$ using far less amounts of catalysts $\left(0.01 \mathrm{~mol} \% \mathrm{~B}\left(\mathrm{C}_{6} \mathrm{~F}_{5}\right)_{3}\right.$ and $0.0001 \mathrm{~mol} \%\left(\mathrm{CH}_{3}\right)_{3} \mathrm{SiOTf}$ (Table II). Obviously, the $\left(\mathrm{CH}_{3}\right)_{3} \mathrm{Si}$ - system is superior to the $\left(\mathrm{C}_{2} \mathrm{H}_{5}\right)_{3} \mathrm{Si}$ - system in reactivity. However, the GTP by the $\left(\mathrm{CH}_{3}\right)_{3} \mathrm{Si}$ - system was sensitive to a minor change in the polymerization conditions such as the amount of $2, \mathrm{~B}\left(\mathrm{C}_{6} \mathrm{~F}_{5}\right)_{3}$, or $\left(\mathrm{CH}_{3}\right)_{3} \mathrm{SiOTf}$, leading to erratic results with respect to the yield and MWD of the polymer. Further study on the polymerization by the $\left(\mathrm{CH}_{3}\right)_{3} \mathrm{Si}$ - system is now under way. The use of toluene instead of $\mathrm{CH}_{2} \mathrm{Cl}_{2}$ as the solvent slowed down the rate of polymerization significantly (Table II).

To demonstrate the living nature of the $\mathrm{B}\left(\mathrm{C}_{6} \mathrm{~F}_{5}\right)_{3}$ $\left(\mathrm{C}_{2} \mathrm{H}_{5}\right)_{3}$ SiOTf-catalyzed GTP, block copolymerization was carried out by polymerizing ethyl acrylate first and adding $n$-butyl acrylate subsequently. Both the first stage polymerization of ethyl acrylate and the second stage polymerization of $n$-butyl acrylate proceeded quantitatively to give poly(ethyl acrylate)-block-poly( $n$-butyl acrylate). Figure 1 shows size exclusion chromatograms of the block copolymer and the poly(ethyl acrylate) prepared in a similar manner as the first stage polymerization. The block copolymer had a narrow MWD without noticeable tailing to the lower molecular weight region, indicating quantitative initiation of the second stage polymerization by living poly(ethyl acrylate).

It should be mentioned that $\mathrm{B}\left(\mathrm{C}_{6} \mathrm{~F}_{5}\right)_{3}$-catalyzed GTP is also useful for the preparation of polymethacrylates with narrow MWDs. $\left(\mathrm{C}_{2} \mathrm{H}_{5}\right)_{3}$ SiI seems to be more effective than $\left(\mathrm{C}_{2} \mathrm{H}_{5}\right)_{3} \mathrm{SiOTf}$ as the co-catalyst for this polymerization. PMMA obtained by the GTP at $-40^{\circ} \mathrm{C}$ was predominantly syndiotactic $(r r=88 \%)$ (Table II). Though optimized conditions are under investigation, the results imply the possibility of copolymerization of acrylate and 


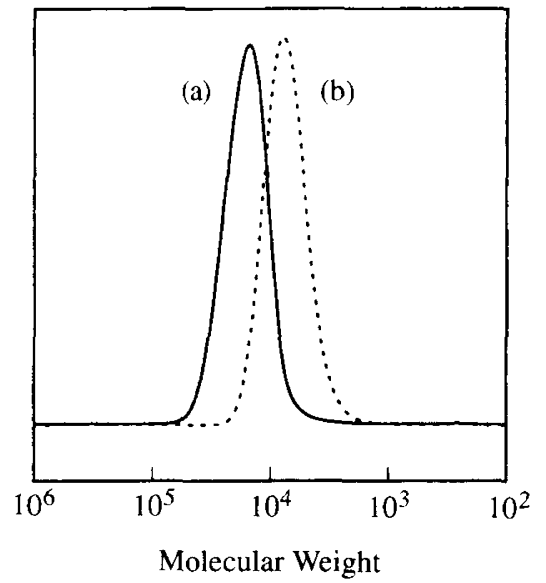

Figure 1. Size exclusion chromatograms of poly(ethyl acrylate)block-poly( $n$-butyl acrylate) (a) and poly(ethyl acrylate) (b) obtained by $\mathrm{B}\left(\mathrm{C}_{6} \mathrm{~F}_{5}\right)_{3}-\left(\mathrm{C}_{2} \mathrm{H}_{5}\right)_{3}$ SiOTf-catalyzed GTP in $\mathrm{CH}_{2} \mathrm{Cl}_{2}$ at $0^{\circ} \mathrm{C}$. The block copolymer (a) was prepared by adding $n$-butyl acrylate to the living poly(ethyl acrylate) ([n-butyl acrylate $]_{0} /$ [ethyl acrylate $]_{0}=$ $1.0 \mathrm{~mol} / \mathrm{mol}$ ) formed under the following conditions: ethyl acrylate, $10 \mathrm{mmol} ; 1$-methoxy-1-(triethylsiloxy)-2-methyl-1-propene, $200 \mu$ mol; $\mathrm{B}\left(\mathrm{C}_{6} \mathrm{~F}_{5}\right)_{3}, 10 \mu \mathrm{mol} ;\left(\mathrm{C}_{2} \mathrm{H}_{5}\right)_{3} \mathrm{SiOTf}, 0.10 \mu \mathrm{mol} ; \mathrm{CH}_{2} \mathrm{Cl}_{2}, 4 \mathrm{~mL}$; polymerization time, $1 \mathrm{~h}$. The block copolymerization was carried out for $2 \mathrm{~h}$ after the addition of $n$-butyl acrylate. The homopolymer (b) was obtained in a quantitative yield by quenching the living poly(ethyl acrylate) described above. Molecular weight was calibrated against standard PMMA samples: (a) $M_{\mathrm{n}}=15000, M_{\mathrm{w}} / M_{\mathrm{n}}=$ $1.19 ;$ (b) $M_{\mathrm{n}}=6800, M_{\mathrm{w}} / M_{\mathrm{n}}=1.18$.

methacrylate.

Living or controlled polymerization of $n$-alkyl acrylates other than GTP has been reported for the polymerization with aluminum porphyrin initiators, ${ }^{22}$ organolanthanides, ${ }^{23}$ diphenylmethyllithium / polydentate lithium alkoxide, ${ }^{24}$ and $t$-butyllithium / ethylaluminum bis $(2,6$ di-tert-butylphenoxide) systems, ${ }^{25}$ and for the atom transfer radical polymerization using $\mathrm{CuBr} /$ multidentate amine systems. ${ }^{26,27}$ The advantage of the GTP described in this communication would be its easiness. Living poly $\left(n\right.$-alkyl acrylate)s with $M_{\mathrm{n}}$ exceeding 20000 can be prepared at room temperature $\left(20^{\circ} \mathrm{C}\right)$ in a reasonable reaction time. This GTP proceeds with very small amounts of $\mathrm{B}\left(\mathrm{C}_{6} \mathrm{~F}_{5}\right)_{3}$ and $\left(\mathrm{C}_{2} \mathrm{H}_{5}\right)_{3} \mathrm{SiOTf}$ as catalysts, both of which are commercially available. Further, the ketene triethylsilyl acetal initiator is readily obtained by the $\left[\left(\mathrm{C}_{6} \mathrm{H}_{5}\right)_{3} \mathrm{P}\right]_{3} \mathrm{RhCl}$-catalyzed hydrosilylation of methyl methacrylate with triethylsilane. ${ }^{28}$

The combination of Lewis acid and silylating agent opens the possibility for advanced control (e.g., stereospecificity) and higher efficiency of GTP.

\section{REFERENCES}

1. O. W. Webster, W. R. Hertler, D. Y. Sogah, W. B. Farnham, and T. V RajanBabu, J. Am. Chem. Soc., 105, 5706 (1983).

2. D. Y. Sogah, W. R. Hertler, O. W. Webster, and G. M. Cohen, Macromolecules, 20, 1473 (1987).

3. I. B. Dicker, G. M. Cohen, W. B. Farnham, W. R. Hertler, E. D. Laganis, and D. Y. Sogah, Macromolecules, 23, 4034 (1990).

4. W. R. Hertler, D. Y. Sogah, O. W. Webster, and B. M. Trost, Macromolecules, 17, 1417 (1984).

5. I. B. Dicker, U. S. Patent 4732955 (Mar. 22, 1988).

6. I. B. Dicker, Polym. Prepr. (Am. Chem. Soc., Div. Polym. Chem.), 29-2, 114 (1988).

7. D. White and K. Matyjaszewski, Polym. Prepr. (Am. Chem. Soc., Div. Polym. Chem.), 36-2, 286 (1995).

8. I. B. Dicker, PCT Int., Appl. 8909236 (Oct. 5, 1989).

9. R. Zhuang and A. H. E. Müller, Macromol. Symp, 85, 379 (1994).

10. R. Zhuang and A. H. E. Müller, Macromolecules, 28, 8035 (1995).

11. R. Zhuang and A. H. E. Müller, Macromolecules, 28, 8043 (1995).

12. K. Ute, T. Tarao, and K. Hatada, Polym. J., 29, 957 (1997).

13. K. Ute, T. Tarao, S. Hongo, H. Ohnuma, K. Hatada, and T. Kitayama, Polym. J., 31, 177 (1999).

14. K. Ute, M. Katsumata, H. Ohnuma, and T. Kitayama, Polym. Prepr. Jpn., 48, 192 (1999).

15. K. Ute, H. Ohnuma, M. Katsumata, and T. Kitayama, Polym. Prepr. Jpn., 48, 1299 (1999).

16. K. Ishihara, N. Hanaki, and H. Yamamoto, Synlett, 577 (1993).

17. K. Ishihara, N. Hanaki, M. Funahashi, M. Miyata, and H. Yamamoto, Bull. Chem. Soc. Jpn., 68, 1721 (1995).

18. H. Sugimoto, T. Aida, and S. Inoue, Macromolecules, 26, 4751 (1993).

19. S. Murata, M. Suzuki, and R. Noyori, J. Am. Chem. Soc., 102, 3248 (1980).

20. R. Noyori, S. Murata, and M. Suzuki, Tetrahedron, 23, 3899 (1981).

21. W. J. Brittain, E. C. Aquino, I. B. Dicker, and D. J. Brunelle, Makromol. Chem., 194, 1249 (1993).

22. Y. Hosokawa, M. Kuroki, T. Aida, and S. Inoue, Macromolecules, 24, 824 (1991).

23. E. Ihara, M. Morimoto, and H. Yasuda, Macromolecules, 28, 7886 (1995).

24. N. Nugay, T. Nugay, R. Jérôme, and Ph. Teyssié, J. Polym. Sci., Part A: Polym. Chem., 35, 361 (1997).

25. T. Kitayama, M. Tabuchi, and K. Hatada, Polym. Prepr. Jpn., 47, 179 (1998).

26. K. Matyjaszewski, Y. Nakagawa, and C. B. Jasieczek, Macromolecules, 31, 1535 (1998).

27. J. Xia, S. G. Gaynor, and K. Matyjaszewski, Macromolecules, 31, 5958 (1998).

28. E. Yoshii, Y. Kobayashi, T. Koizumi, and T. Oribe, Chem. Pharm. Bull., 22, 2767 (1974). 